\title{
PERTANGGUNGJAWABAN PIDANA KORUPSI KORPORASI
}

\author{
(Corruption Corporate Criminal Liability)
}

\author{
Henry Donald Lbn. Toruan \\ Pusat Penelitian dan Pengembangan Sistem Hukum Nasional \\ Badan Pembinaan Hukum Nasional \\ Jl. Mayjen Sutoyo Nomor 10 Cililitan Jakarta \\ Email: henry.d@bphn.go.id
}

Naskah diterima: 14 Oktober 2014; revisi: 17 Nopember 2014; disetujui: 28 Nopember 2014

\begin{abstract}
Abstrak
Pemeriksaan Komisi Pemberantasan Korupsi (KPK) selama ini, masih seputar pelaku orang-perseorangan seperti pegawai negeri, pejabat publik, anggota DPR, direksi dan pegawai perusahaan. Belum menyentuh orang perseorangan diluar individu, yang dikenal sebagai badan hukum atau korporasi. Padahal Undang-Undang Nomor 20 Tahun 2001 tentang Perubahan Undang-Undang Nomor 31 Tahun 1999 tentang Pemberantasan Tindak Pidana Korupsi (UUPTPK) dalam Pasal 1 ayat (3), telah menetapkan korporasi sebagai subjek tindak pidana korupsi. Tetapi kenyataannya, pemidanaan korporasi hampir jarang tersentuh. Sementara masyarakat menghendaki agar korporasi yang melakukan tindak pidana korupsi dijatuhi pidana. Oleh karena itu penting untuk dibahas dengan menggunakan metode normatif apakah korporasi merupakan subyek tindak pidana korupsi dan bagaimana bentuk pertanggung jawaban hukumnya apabila korporasi dianggap sebagai pelaku tindak pidana korupsi. Jika mengacu pada Pasal 2 ayat (1) UUPTPK berikut penjelasannya, maka tindak pidana korupsi korporasi merupakan perbuatan melawan hukum baik dalam arti formil maupun dalam arti materiil, yang perbuatannya dapat dipidana. Namun pertanggungjawaban pidana pada perbuatan melawan hukum dalam arti formil mengalami kesulitan karena hukum pidana menganut asas legalitas dimana unsur kesalahan mutlak harus dipenuhi agar seseorang dapat dipidana. Pertanggungjawaban yang mungkin dilakukan terhadap korporasi yang melakukan perbuatan melawan hukum tindak pidana korupsi adalah dalam pidana bentuk lain.
\end{abstract}

Kata Kunci: korporasi, korupsi, pertanggungjawaban.

\section{Abstract}

The examination of the Corruption Eradication Commission (KPK) over the years, is still about individuals actors such as civil servants, public officials, members of Parliament, directors and employees of the company. Besides those individual actors, there is also legal entity called corporation that has not been touched by the KPK. Eventough Law Number 20 year 2001 regarding the Amendment of Law Number 31 year 1999 on the Eradication of Corruption (UUPTPK) in Article 1 verse (3) have been mentioned corporation as the subject of corruption. But in reality, the corporation almost rarely touched criminal prosecution. While society wants corporations did corruption to be punished. Thus becomes important to discuss using normative research method whether corporation may be subject to criminal sanctions and how the format of the legal liability if corporation treated as corruption legal subject. Referring to Article 2 verse (1) UUPTPK follow this for explanation, it stated that the corporate corruption is both a tort in the sense both in formal and material sense, that his deeds may be liable. But criminal liability in tort in a formal sense finds difficulty in criminal laws adhere to the principle of legality where the absolute error element must be met in order for a person can be convicted. Accountability may be made against corporation that committed an unlawful act of corruption in another form of criminal.

Keywords: corporate, corruption, responsibility. 


\section{A. Pendahuluan}

Tindak pidana korupsi korporasi merupakan fenomena yang berkembang pesat dewasa ini. Perbuatan pidana tersebut dilakukan dengan berbagai modus, menyimpang dari ketentuan hukum yang berlaku dengan tujuan menguntungkan perusahaan. Perbuatan korupsi korporasi tersebut membawa dampak kerugian pada perekonomian dan keuangan negara, yang berdampak pada pembangunan dan kesejahteraan masyarakat. Namun penegakan hukum terhadap tindak pidana korupsi korporasi, sangat jarang dihadapkan di pengadilan. Biasanya pengurus korporasi saja yang mewakili perseroan di muka hukum. Sementara masyarakat menghendaki agar korupsi yang dilakukan korporasi tidak cukup menjerat Direksinya saja, tapi menjatuhkan juga sanksi pidana pada korporasinya.

Tindak pidana korupsi yang diperiksa Komisi Pemberantasan Korupsi (KPK) dan diputus Pengadilan Tindak Pidana Korupsi (TIPIKOR), masih seputar tindak pidana yang dilakukan individu seperti pegawai negeri, pejabat publik, anggota DPR dari partai politik, direksi dan pegawai perusahaan. Dengan kata lain belum menjangkau orang perseorangan lainnya diluar individu yang dikenal sebagai badan hukum atau korporasi. Pada hal Undang-Undang Nomor 31 Tahun 1999 jo Undang-Undang Nomor 20 Tahun 2001 tentang Pemberantasan Tindak Pidana Korupsi (UUPTPK) telah menetapkan korporasi sebagai subjek tindak pidana korupsi.

Meskipun UUTPK telah menetapkan korporasi sebagai subjek hukum pidana tetapi menurut Surya Jaya, Hakim Agung Kamar Pidana MA, bahwa penegak hukum masih sangat jarang menyentuh kejahatan yang dilakukan korporasi. la mengatakan, jika suatu tindak pidana dilakukan atau bahkan hanya diperintahkan oleh pengurus korporasi. Korporasi itu bisa dijerat. Dia menegaskan, sanksi pidana yang harus diberikan kepada korporasi tidak cukup hanya pidana denda saja. Korporasi yang melakukan kejahatan, seharusnya dikenai pidana pengembalian aset. ${ }^{1}$

Minimnya tindakan hukum terhadap korporasi yang melakukan tindak pidana korupsi, sehingga ICW meminta Komisi Pemberantasan Korupsi (KPK) menjerat korporasi atau perusahaan yang terlibat kasus korupsi. Misalnya menjerat PT Duta Graha Indah (DGI) terkait proyek wisma atlet atau menjerat PT Adhi Karya dan PT Wijaya Karya dalam kasus Hambalang. Supaya mendapat proyek tersebut, diduga PT Adhi Karya rela menggelontorkan uang miliaran rupiah kepada sejumlah pihak. Utamanya, ke pihak Kementerian Pemuda dan Olahraga. ${ }^{2}$ Dugaan korupsi korporasi lainnya, dilakukan anggota Direksi PT Indoguna Utama menyuap seorang petinggi partai. Tujuannya agar petinggi partai itu bisa mengondisikan kepada salah satu kementerian guna memberikan izin tambahan kuota impor sapi kepada perseroan terbatas tersebut. Selain itu ada dugaan beberapa pejabat Kabupaten Bogor menerima suap dari petinggi PT Garindo Perkasa agar mereka mau menyesuaikan peruntukan ribuan hektar tanah dengan keinginan si pengusaha. Terhadap kedua dugaan kasus tindak pidana itu, sampai sejauh ini, diberitakan bahwa KPK hanya menetapkan

http://nasional.kompas.com/read/2013/07/30/1320464 (diakses 15 September 2014).

http://nasional.inilah.com/read/detail/2063880/ (diakses 15 September 2014). 
beberapa orang petinggi di PT Indoguna Utama sebagai tersangkanya. Padahal, dugaan tindak pidana korupsi itu dilakukan para pengurus PT untuk kepentingan dan keuntungan PT dan dalam lingkup operasional PT-nya. ${ }^{3}$

Dari beberapa tindak pidana korupsi yang dilakukan korporasi tampaknya baru pada fase pertanggungjawaban pengurus perseroan, belum sampai menjerat korporasinya. Oleh karena itu, tulisan ini ingin mengulas korporasi sebagai subjek hukum yang dapat dimintakan pertanggungjawaban hukum. Dari uraian latar belakang yang telah dikemukakan di atas, maka penulis mengangkat permasalahan apakah korporasi merupakan subyek tindak pidana korupsi dan bagaimana bentuk pertanggung jawaban hukumnya apabila korporasi dianggap sebagai pelaku tindak pidana korupsi.

\section{B. Metode Penelitian}

Penelitian yang dilakukan dalam penulisan ini menggunakan penelitian hukum normatif atau kepustakaan, mengingat masalah yang diteliti adalah menyangkut bahan hukum seperti peraturan perundang-undangan dan literatur hukum. Metode analisis data yang digunakan dalam penelitian ini adalah metode analisis normatif kualitatif. Analisis normatif karena penelitian ini bertolak dari peraturan perundang-undangan yang berlaku sebagai norma hukum positif, sedangkan kualitatif yaitu tata cara penelitian yang dipusatkan untuk memperoleh data deskriptif.

\section{Pembahasan}

\section{Subyek Tindak Pidana Korupsi}

Chidir Ali mengatakan bahwa lazimnya dalam hukum dan pergaulan hukum dikenal dengan istilah subjek hukum (subjectum juris). Tetapi manusia bukanlah satu-satunya subjek hukum, karena masih ada subjek hukum lainnya yaitu segala sesuatu yang menurut hukum dapat mempunyai hak dan kewajiban, termasuk ini apa yang dinamakan badan hukum (rechtspersoon). ${ }^{4}$ Pertanyaan mengenai apa badan hukum itu, jawabannya dapat bertitik tolak dari jawaban apa subjek hukum yang pengertian pokoknya terumus, yaitu: (1) manusia dan (2) segala sesuatu yang berdasarkan tuntutan kebutuhan masyarakat yang demikian itu oleh hukum diakui sebagai pendukung hak dan kewajiban. Menurut Chidir Ali, pada rumusan yang ke (2) atau terakhir inilah merupakan jawaban apa badan hukum itu. $^{5}$ Selanjutnya disebutkan bahwa badan hukum itu ada dua macam, yaitu: (1) korporasi (corporatie), dan (2) yayasan (stichting). ${ }^{6}$ Yang dimaksud dengan korporasi ialah suatu gabungan orang yang dalam pergaulan hukum bertindak bersama-sama sebagai satu subjek hukum tersendiri suatu personifikasi. Korporasi adalah badan hukum yang beranggota, tetapi mempunyai hak kewajiban sendiri yang terpisah dari hak kewajiban anggota masingmasingnya. ${ }^{7}$ Gabungan orang-orang sebagai anggota perseroan inilah dalam hukum perdata dikenal sebagai organ perseroan, yang terdiri

\footnotetext{
http://www.antikorupsi.org/en/content/ (diakses 15 September 2014).

Chidir Ali, Badan Hukum, (Bandung: Alumni, 2005), hal. 4-5.

Ibid, hal. 18.

Ibid, hal. 63.

Ibid, hal. 64 .
} 
dari Direksi, Komisaris dan RUPS. Jadi, dalam hukum perdata sudah lama diakui korporasi sebagai subjek hukum yang pertama sekali dulu diatur dalam KUHDagang, kemudian diubah dan diganti dengan Undang-Undang Nomor 1 Tahun 1995 tentang Perseroan Terbatas dan terakhir diganti dengan Undang-Undang Nomor 40 Tahun 2007.

Berbeda dengan KUHPidana yang masih berpegang teguh pada adagium bahwa badan hukum tidak dapat dipidana dengan anggapan:

a. Korporasi tidak mempunyai mens rea (keinginan berbuat jahat);

b. Korporasi bukan seorang pribadi meskipun korporasi dapat melakukan berbagai perbuatan hukum yang biasanya dilakukan oleh orang pribadi;

c. Korporasi tidak memiliki kesadaran dan tidak punya badan aktual (no soul to be damned and no body to be kicked);

d. Korporasi tidak dapat dimintai pertanggungjawaban karena jika ada kejahatan yang dilakukan oleh direksi suatu korporasi, hal tersebut sudah pasti merupakan perbuatan di luar anggaran dasar dari korporasi yang bersangkutan, sehinggga dalam hal seperti itu maka yang bertanggung jawab adalah direksinya secara pribadi atau secara bersama-sama dengan direksi lain, tetapi bukan korporasi yang harus bertanggung jawab (doktrin ultra vires). ${ }^{8}$

Namun seiring dengan perkembangan kegiatan ekonomi dan pembangunan di Indonesia, dituntut perlunya peraturan perundangan-undangan yang mengatur tindak pidana secara khusus seperti di bidang perbankan, pasar modal, larangan monopoli dan persaingan usaha tidak sehat, lingkungan hidup, perlindungan konsumen, minyak dan gas bumi, pencucian uang dan sebagainya. Pada umumnya ketentuan di bidang ekonomi ini telah menetapkan korporasi sebagai subjek hukum pidana, yang menyimpang dari ketentuan pidana umum yang diatur dalam KUHP. Meskipun telah diakui korporasi sebagai subjek hukum tapi menurut Muladi, korporasi sebagai subjek tindak pidana masih merupakan hal yang baru, dan tercantum dalam perundangundangan, tetapi proses penegakan hukumnya masih sangat lambat. ${ }^{9} \mathrm{Di}$ Indonesia dalam perundang-undangan baru muncul dan dikenal badan hukum/korporasi sebagai subjek tindak pidana pada tahun 1951, yaitu dalam Undangundang Penimbunan Barang-barang dan mulai dikenal secara luas dalam Undang-Undang Nomor 7 Drt Tahun 1955 tentang Tindak Pidana Ekonomi. ${ }^{10}$

Hal senada dikemukakan S.R. Sianturi bahwa dalam perkembangan hukum pidana selanjutnya bukan hanya manusia yang dianggap sebagai subjek, terutama dalam halhal yang menyangkut:

a. sumber keuangan negara (perpajakan, bea import dan eksport barang dan lain sebagainya);

b. pengaturan perekenomian (pengendalian harga, penggunaan cek, pengaturan perusahaan dan sebagainya);

R. Rufinus Hotmaulana Hutauruk, Penanggulangan Kejahatan Korporasi Melalui Pendekatan Restoratif: Suatu Terobosan Hukum, (Jakarta: Sinar Grafika, 2013), hal. 22.

9 Muladi dan Dwidja Priyatno, Pertanggungjawaban Pidana Korporasi, (Jakarta: Prenadamedia, 2013), hal. 13.

10 Andi Hamzah dalam Muladi, Ibid, hal. 14. 
c. pengaturan keamanan (subversi, keadaan bahaya, dan lain sebagainya); ${ }^{11}$

Ketentuan mengenai badan hukum sebagai subjek antara lain dapat ditemukan dalam Undang-undang Tindak Pidana Ekonomi (Undang-undang No. 7 Drt Tahun 1955 L.N. No.188 Tahun 1960) pada Pasal 15 disebut antara lain: ayat (1) jika suatu tindak pidana ekonomi dilakukan oleh atau atas nama suatu badan hukum, suatu perserikatan orang yang lainnya, atau suatu yayasan maka tuntutan pidana dilakukan dan hukuman pidana serta tindakan tata tertib dijatuhkan, baik terhadap badan hukum, perseroan, perserikatan atau yayasan itu, baik terhadap mereka yang memberi perintah melakukan tindak pidana ekonomi itu atau yang bertindak sebagai pimpinan dalam perbuatan atau kelalaian itu, maupun terhadap dua-duanya. ${ }^{12}$ Dengan demikian, korporasi sebagai subjek hukum pidana di Indonesia hanya ditemukan dalam perundang-undangan khusus di luar KUHP, yang merupakan pelengkap KUHP, sebab untuk hukum pidana umum atau KUHP itu sendiri masih menganut subjek hukum pidana secara umum, yaitu manusia (Pasal 59 KUHP). ${ }^{13}$

Dalam perkembangan hukum pidana khusus bidang korupsi sudah menetapkan korporasi sebagai subjek hukum disamping orang. Hal ini dapat dibaca dalam Pasal 1 ayat (3) Undang-Undang Nomor 31 Tahun 1999 tentang Pemberantasan Tindak Pidana
Korupsi (UUPTPK) yang menyebutkan bahwa "Setiap orang adalah orang perseorangan atau termasuk korporasi. Jika yang dimaksudkan orang perseorangan itu termasuk korporasi, maka secara hipotetis bahwa setiap korporasi yang melakukan perbuatan melawan hukum memperkaya diri sendiri atau orang lain atau korporasi yang dapat merugikan keuangan negara atau perekonomian negara dapat dipidana sebagaimana ditentukan dalam Pasal 2 ayat (1) UUPTPK. Dengan demikian korporasi dalam UUPTPK sudah ditentukan sebagai subjek hukum dan karena itu dapat dimintakan pertanggung jawaban pidana.

Meskipun korporasi telah ditentukan sebagai subjek hukum dalam berbagai ketentuan pidana khusus tetapi penegakan hukum terhadap korporasi yang melakukan tindak pidana korupsi masih sangat sulit dilaksanakan. Andi Hamzah mengatakan bahwa dalam delik korupsi terlihat banyak kesulitan untuk menjadikan korporasi sebagai subjek karena sulit membuktikan adanya kesalahan terutama dalam bentuk 'sengaja' suatu korupsi. Lagi pula orang yang tidak bersalah bisa terkena getahnya, misalnya karyawan perusahaan yang di-PHK jika perusahaan ditutup. Begitu pula pemegang saham yang tidak tahu-menahu mengenai kejahatan itu akan ikut membayar denda yang diambil dari keuntungan sahamnya. Tentulah tidak semua delik korupsi korporasi dapat menjadi subjek. Semua rumusan delik

11 S.R. Sianturi, Asas-asas Hukum Pidana di Indonesia dan Penerapannya, (Jakarta: Alumni AHAEM - PETEHAEM, 1996), hal. 218-219.

12 Pasal 4.2 Terms of Reference the ASEAN Intergovernmental Commission on Human Rights menyebutkan bahwa, mandat Komisi untuk membentuk Deklarasi HAM ASEAN dengan pandangan untuk membangun kerangka kerja untuk kerjasama hak asasi manusia melalui berbagai konvensi ASEAN dan instrumen terkait hak asasi manusia Ibid, hal. 219.

13 Muladi dan Dwidja Priyatno, op.cit, hal. 13 
yang subjeknya mempunyai kualitas tertentu sebagai "pegawai negeri atau pejabat" tidak mungkin korporasi menjadi subjek delik. ${ }^{14}$ Dengan ditetapkannya korporasi sebagai subjek hukum, juga mendapat tanggapan dari ahli hukum Muladi yang mengatakan bahwa dengan diterimanya korporasi sebagai subjek tindak pidana, hal ini menimbulkan permasalahan dalam hukum pidana di Indonesia, khususnya yang menyangkut masalahan pertanggungjawaban pidana pada korporasi. ${ }^{15}$ Yaitu apakah badan hukum dapat mempunyai kesalahan, baik berupa kesengajaan maupun kealpaan. ${ }^{16}$

Penetapan korporasi sebagai subjek hukum tindak pidana korupsi yang tidak selaras dengan ketentuan pidana umum dalam KUHP, akan membawa berbagai implikasi terutama dalam penegakan hukumnya. Sebagaimana dikatakan di atas betapa sulitnya menentukan kesalahan pada korporasi sehingga yang sering dinyatakan bersalah hanyalah pengurus korporasi. Hal ini dapat terjadi karena pasal-pasal KUHP merupakan satu-kesatuan ibarat suatu sistem yang berbeda dengan sistem yang dianut dalam UUPTPK. Sehingga pasal-pasal KUHP yang ditarik masuk ke dalam UUPTPK akan mengalami kesulitan dalam penerapannya. Jika yang dimaksudkan itu orang termasuk korporasi dalam UUPTPK berarti badan hukum ini dapat dijatuhkan sanksi pidana penjara sebagaimana diatur dalam KUHP. Tetapi akan menemukan kesulitan bagaimana memenjarakan korporasi karena ia hanyalah manusia buatan (fiksi) yang tidak berwujud. Oleh karena itu, perubahan KUHP yang sedang dalam pembahasan di DPR mudah-mudahan sudah menetapkan korporasi sebagai subjek hukum. Sehingga terdapat kesesuaian pengaturan dalam pidana umum dan pidana khusus.

Hukum pidana adalah bagian dari keseluruhan hukum yang berlaku di suatu negara, yang mengadakan dasar-dasar dan aturan-aturan untuk:

a. Menentukan perbuatan-perbuatan mana yang tidak boleh dilakukan, yang dilarang, dengan disertai ancaman atau sanksi yang berupa pidana tertentu bagi barang siapa melanggar larangan tersebut;

b. Menentukan kapan dan dalam hal-hal apa kepada mereka yang telah melanggar larangan-larangan itu dapat dikenakan atau dijatuhi pidana sebagaimana yang telah diancam;

c. Menentukan dengan cara bagaimana pengenaan pidana itu dapat dilaksanakan apabila ada orang yang disangka telah melanggar larangan tersebut. ${ }^{17}$

Perbuatan-perbuatan pidana ini menurut wujud atau sifatnya adalah bertentangan dengan tata atau ketertiban yang dikehendaki oleh hukum, mereka adalah perbuatan yang melawan (melanggar) hukum. Tegasnya: mereka merugikan masyarakat, dalam arti bertentangan dengan atau menghambat akan terlaksananya tata dalam pergaulan

14 Andi Hamzah, Pemberantasan Korupsi Melalui Hukum Pidana Nasional dan Internasional, (Jakarta: Rajawali Pers, 2012), hal. 80-81.

15 Ibid

16 Ibid, hal. 18

17 Moeljatno, Asas-asas Hukum Pidana, (Jakarta : Rineka Cipta, 2009), hal. 1 
masyarakat yang baik dan adil. Dapat pula dikatakan bahwa perbuatan-perbuatan pidana itu bersifat merugikan masyarakat, jadi anti sosial. Karenanya perbuatan-perbuatan itu dilarang keras atau pantang dilakukan. ${ }^{18}$ Tentang penentuan perbuatan mana yang dipandang sebagai perbuatan pidana, kita menganut asas yang dinamakan asas legalitas (principle of legality), yakni asas yang menentukan bahwa tiap-tiap perbuatan pidana harus ditentukan sebagai demikian oleh suatu aturan undangundang (Pasal 1 ayat 1 KUHP). ${ }^{19}$

Istilah perbuatan pidana atau tindak pidana merupakan terjemahan dari istilah yang digunakan dalam KUHP Belanda. Martiman Prodjohamidjojo menyebutkan ada dua istilah yang dipakai dalam bahasa Belanda, yaitu stafbaar feit dan istilah delict yang mempunyai makna sama. Delict diterjemahkan dengan delik saja, sedangkan stafbaar feit dalam bahasa Indonesia mempunyai beberapa arti dan belum diperoleh kata sepakat diantara para sarjana Indonesia mengenai alih bahasa. Ada yang menggunakan terjemahan: perbuatan pidana (Moeljatno dan Roeslan Saleh); peristiwa pidana (Konstitusi RIS, UUDS 1950 Tresna serta Utrecht); tindak pidana (Wirjono Projodikoro); delik (Satochid Kartanegara, A.Z. Abidin dan Andi Hamzah); perbuatan yang boleh dihukum (Karni dan van Schravendijk); pelanggaran pidana (Tirtaamidjaja). ${ }^{21}$ Pembentuk undang-undang kita telah menggunakan perkataan "stafbaar feit" untuk menyebutkan apa yang kita kenal sebagai “tindak pidana” di dalam Kitab UndangUndang Hukum Pidana tanpa memberikan sesuatu penjelasan mengenai apa yang sebenarnya yang dimaksud dengan perkataan "stafbaar feit" tersebut. ${ }^{22}$ Dengan demikian dalam literatur hukum pidana ditemukan berbagai istilah yang digunakan penulis sebagai terjemahan dari istilah stafbaar feit dan delict. Dalam penulisan jurnal ini menggunakan istilah tindak pidana, yang lebih umum digunakan oleh masyarakat.

Meskipun tidak terdapat penjelasan mengenai maksud dari tindak pidana, tetapi menurut Lamintang bahwa setiap tindak pidana yang terdapat di dalam Kitab UndangUndang Hukum Pidana itu pada umumnya dapat kita jabarkan ke dalam unsur-unsur yang pada dasarnya dapat kita bagi menjadi dua macam unsur, yakni unsur-unsur subjektif dan unsur-unsur objektif. Yang dimaksud dengan unsur-unsur subjektif itu adalah unsurunsur yang melekat pada diri si pelaku atau yang berhubungan dengan diri si pelaku, dan termasuk di dalamnya yaitu segala sesuatu yang terkandung di dalam hatinya. Sedang yang dimaksud dengan unsur-unsur objektif itu adalah unsur-unsur yang ada hubungannya dengan keadaan-keadaan, yaitu di dalam keadaan-keadaan mana tindakan-tindakan dari si pelaku itu harus dilakukan. ${ }^{22}$

Selanjutnya S.R. Sianturi merumuskan unsur-unsur dari tindak pidana, yaitu:

\footnotetext{
Ibid, hal. 3.

Ibid, hal. 5 .

20 Martiman Prodjohamidjojo, Memahami Dasar-Dasar Hukum Pidana Indonesia, (Jakarta : Pradnya Paramita, 1997), hal. 15.

21 P.A.F. Lumintang, Dasar-Dasar Hukum Pidana Indonesia, (Bandung : Citra Aditya Bakti, 1997), hal. 181.

22 Ibid, hal. 193.
} 


\author{
ke - 1 Subjek; \\ ke -2 Kesalahan; \\ ke -3 Bersifat melawan hukum (dari suatu \\ tindakan); \\ ke-4 Suatu tindakan yang dilarang atau \\ diharuskan oleh undang-undang/ \\ perundang-undangan dan terhadap \\ pelanggarannya diancam dengan \\ pidana; \\ ke-5 Waktu, tempat dan keadaan (unsur \\ objektif lainnya). ${ }^{23}$
}

Dalam Sistem Common Law (Hukum Inggris), setiap orang yang melakukan pelanggaran terhadap undang-undang pidana harus memenuhi unsur-unsur sebagai berikut:

a. tertuduh telah melakukan perbuatan yang dituduhkan atau dikenal dengan istilah Actus-reus; dan

b. tertuduh melakukan pelanggaran terhadap undang-undang dengan disertai niat jahat atau dikenal dengan istilah Mens-rea. ${ }^{24}$

Menurut hukum pidana Inggris, Actusreus mengandung prinsip bahwa perbuatan yang dituduhkan secara langsung dilakukan tertuduh. Pada prinsipnya seseorang tidak dapat dipertanggungjawabkan atas perbuatan orang lain, kecuali ia membujuk orang lain untuk melakukan pelanggaran undangundang atau tertuduh memiliki tujuan yang sama dengan pelaku pelanggaran tersebut. Selain itu, perbuatan yang dituduhkan harus dilakukan tertuduh dengan sukarela (tanpa ada paksaan dari pihak (ain) atau perbuatan dan akibatnya memang dkehendaki oleh tertuduh. Selanjutnya, ketidaktahuan akan undangundang yang berlaku bukan merupakan alasan pemaaf/yang dapat dipertanggungjawabkan. ${ }^{25}$

\section{Pertanggungjawaban Korporasi}

\section{a. Perbuatan Melawan Hukum dalam Tindak Pidana Korupsi.}

Perbuatan melawan hukum (pidana) yang disebut dengan tindak pidana oleh korporasi (kelompok/badan hukum) dalam menjalankan kegiatan usahanya adalah merupakan kejahatan korporasi yang menimbulkan kerugian yang sangat besar terhadap sebagian besar rakyat/ masyarakat yang sedang membangun/menata kehidupannya. Kejahatan (tindak pidana) korporasi mempunyai jangkauan kejahatan yang begitu luas dengan berbagai bentuk perbuatan dalam rangka mencapai tujuantujuan korporasi, seperti masalah-masalah suap atau pemberian "uang pelicin" merupakan salah satu perilaku yang sangat menonjol dalam kejahatan korporasi. ${ }^{26}$ Tujuan utama suatu korporasi sesuai prinsip ekonomi adalah mencari keuntungan sebesar-besarnya dengan mengeluarkan modal sekecil-kecilnya. Dalam rangka mencari keuntungan ini kerap korporasi melakukan praktek-praktek penyimpangan yang sudah mengarah pada kejahatan yang melanggar perundang-undangan.

Yang dimaksud dengan kejahatan (tindak pidana) korporasi menurut Marshall B. Clinard dan Peter $C$ Yeager adalah sbb: "A corporate 
crime is any act committed by corporation that is punished by the state, regardless of whether it is punished under administrative, civil, or criminal law" (kejahatan korporasi ialah setiap tindakan yang dilakukan oleh korporasi yang bisa diberi hukuman oleh negara, entah di bawah hukum administrasi negara, hukum perdata, maupun hukum pidana). ${ }^{27}$ Agar tidak terjadi kerancuan dengan berbagai istilah yang berkaitan dengan korporasi, maka harus diadakan pembedaan antara(1)crimeforcorporation,(2)crimesagaints corporation dan (3) criminal corporations. ${ }^{28}$ Dari ketiga istilah kejahatan korporasi tersebut, Crimes for corporation inilah yang merupakan kejahatan korporasi (corporate crimes). Dalam hal ini dapat dikatakan, "corporate crime are clearly committed for the corporate, and not against." Kejahatan korporasi dilakukan untuk kepentingan korporasi dan bukan sebaliknya, kejahatan terhadap korporasi (crime against corporations), yang sering dinamakan employee crimes, yaitu kejahatan yang dilakukan oleh para karyawan atau pekerja terhadap korporasi, misalnya penggelapan dana perusahaan oleh pejabat atau karyawan perusahaan tersebut. ${ }^{29}$

Kejahatan (tindak pidana) korporasi merupakan perilaku korporasi yang tidak sah dalam bentuk pelanggaran hukum kolektif dengan tujuan untuk mencapai tujuan organisasi, yang mempunyai karakteristik sebagai berikut:

1) Kejahatan tersebut sulit dilihat (low visibility) karena biasanya tertutup oleh kegiatan pekerjaan normal yang rutin, melibatkan keahlian profesional dan sistem organisasi yang kompleks (complexity).

2) Kejahatan tersebut sangat kompleks (complexity), karena selalu berkaitan dengan kebohongan, penipuan dan pencurian serta seringkali berkaitan dengan sesuatu yang ilmiah, teknologi, finansial, legal, terorganisasi, melibatkan banyak orang serta berjalan bertahun-tahun.

3) Terjadinya penyebaran tanggung jawab (diffusion of responsibility) yang semakin luas akibat kompleks organisasi.

4) Penyebaran korban yang luas (disffusion of victimization), seperti polusi, penipuan konsumen dan sebagainya.

5) Hambatan dalam pendeteksian dan penuntutan (detection and prosecution) sebagai akibat profesionalisme yang tidak seimbang antara aparat penegak hukum dan pelaku tindak pidana.

6) Peraturan yang tidak jelas (ambiquous laws), yang sering menimbulkan keraguan dalam penegakan hukum. Dalam bidang hukum ekonomi, hal semacam ini sangat dirasakan, misalnya sebagai akibat regulasi.

7) Ambiguitas (sikap mendua) terhadap status pelaku tindak pidana. Dalam tindak pidana ekonomi, secara jujur harus diakui bahwa pelaku tindak pidana bukanlah orang secara moral salah (mala per se), tetapi karena melanggar peraturan yang dibuat pemerintah untuk melindungi kepentingan umum (mala prohibita). ${ }^{30}$

Tindak pidana yang dilakukan oleh korporasi tergolong pada kejahatan yang tidak biasa tapi

\footnotetext{
27 H. Setiyono, Kejahatan Korporasi: Analisis Viktimonologis Dan Pertanggungjawaban Korporasi Dalam Hukum Pidana Indonesia, (Malang : Averros Press, 2002,) hal 27.

28 H. Setiyono, Op.cit, hal. 27.

29 H. Setiyono, Op.cit, hal. 27.

30 Ibid, hal. 54-55
} 
dapat menimbulkan dampak luar biasa bagi kerugian perekonomian dan keuangan negara serta masyarakat. Namun KUHP yang berlaku sekarang belum mengatur perbuatan melawan hukum korporasi, sehingga perlu diatur dalam peraturan pidana khusus. Yang dimaksud dengan hukum pidana khusus menurut Sudarto adalah hukum pidana yang ditetapkan untuk golongan-golongan orang khusus atau yang berhubungan dengan perbuatan-perbuatan khusus. ${ }^{31}$ Di samping hukum pidana khusus ini hukum pidana umum (ius commune) tetap berlaku sebagai hukum yang menambah (aanvullend recht). ${ }^{32}$ Jadi, UUPTPK termasuk hukum pidana khusus yang dibentuk untuk memberantas perbuatan-perbuatan khusus di bidang korupsi yang menyimpang dari pidana umum. Salah satu aturan yang menyimpang dari pidana umum dalam pembentukan UUPTPK adalah memasukkan korporasi sebagai subjek hukum, yang dapat dimintakan pertanggung jawaban bila melakukan perbuatan melawan hukum. Ketentuan pidana umum yang diatur dalam KUHP hanya mengenal manusia sebagai subjek hukum dan tidak mengenal subjek hukum korporasi.

Dalam upaya memberantas tindak pidana korupsi di Indonesia, pemerintah telah menerbitkan berbagai ketentuan perundangundangan yang pertama kali adalah Peraturan Penguasa Militer tanggal 9 April 1957 Nomor Prt/PM/06/1957, tanggal 27 Mei 1957 Nomor Prt/PM/03/1957, dan tanggal 1 Juli 1957 Nomor Prt/PM/011/1957. Ketiga peraturan tersebut di atas kemudian diganti dengan Peraturan Pemberantasan Korupsi Prn Penguasa Perang
Pusat Nomor Prt/Peperpu/013/1958. Lalu peraturan penguasan perang ini berikutnya diganti dengan Undang-undang (Prp) Nomor 24 Tahun 1960 tentang Pemberantasan Tindak Pidana Korupsi, yang kemudian undang-undang ini pun diganti dengan Undang-Undang Nomor 3 Tahun 1971 tentang Pemberantasan Tindak Pidana Korupsi. Memasuki masa reformasi tahun 1998, masyarakat menuntut perubahan terhadap UUPTPK No. 3 Tahun 1971 guna memberantas tindak pidana korupsi yang merajalela pada masa Orde Baru. Pemerintah bersama DPR akhirnya melakukan perubahan terhadap UUPTPK No. 3 Tahun 1971 dengan UUPTPK No. 31 Tahun 1999 yang kemudian dirubah kembali dengan Undang-Undang Nomor 20 Tahun 2001 tentang Perubahan Atas Undang-Undang Nomor 31 Tahun 1999 tentang Pemberantasan Tindak Pidana Korupsi.

Sebelum diterbitkannya Undang-Undang Nomor 31 Tahun 1999 ternyata perbuatan melawan hukum belum menjangkau korporasi sebagai subjek hukum pelaku tindak pidana korupsi, masih menitik beratkan pada tindak pidana korupsi yang dilakukan orang perseorangan saja. Bahkan dalam Peraturan Penguasa Perang Pusat tersebut di atas ada ketentuan yang dikategorikan sebagai perbuatan korupsi pidana dan perbuatan korupsi lainnya (Pasal 1). Setelah dilakukan perubahan Peraturan Penguasa Perang Pusat menjadi Undang-Undang (Prp) Nomor 24 Tahun 1960 tentang Pemberantasan Tindak Pidana Korupsi, dalam penjelasan umum dikatakan bahwa Undang-undang ini tidak mengambil alih ketentuan tentang perbuatan korupsi bukan

Sudarto, Kapita Selekta Hukum Pidana, (Bandung: Alumni, 1986), hal. 61.

32 Ibid, hal. 61 
pidana. Tetapi menjelaskan apa yang dimaksud dengan "Perbuatan korupsi lainnya," dimana terdapat unsur "perbuatan melawan hukum" (Pasal 3). Perbuatan korupsi ini tidak diancam dengan hukum pidana, melainkan Pengadilan Tinggi yang mengadilinya atas gugatan Badan Koordinasi Pemilik Harta Benda, dapat merampas harta benda hasil perbuatan korupsi itu. Menurut Andi Hamzah bahwa pengertian unsur "perbuatan melawan hukum" tersebut di atas ialah onrechtmatigedaad tercantum dalam Pasal 1365 KUHPerdata, yang menurut yurisprudensi mempunyai makna sangat luas, yaitu perbuatan atau kelalaian seseorang sehingga melanggar hak orang lain atau bertentangan dengan kewajibannya sendiri menurut hukum atau dengan norma-norma adat kesopanan yang lazim ataupun bertentangan dengan keharusan dalam pergaulan hidup untuk bertindak prihatin terhadap orang lain atau barang-barang cq haknya. ${ }^{33}$ Dapatlah kita singkatkan makna dari perkataan "perbuatan melawan hukum" tersebut dengan istilah "perbuatan tercela." Harta benda hasil perbuatan tercela inilah yang dapat dirampas oleh Pengadilan Tinggi. ${ }^{34}$

Pada hakekatnya perumusan perbuatan melawan hukum dalam tindak pidana korupsi, merupakan pengambilalihan perumusan dari peraturan perundang-undangan yang telah disebut di atas dengan melakukan beberapa perubahan-perubahan. Dalam Undang-Undang Nomor 31 Tahun 1999 perbuatan melawan hukum tindak pidana korupsi diatur pada Pasal 2 ayat (1) yang menyebutkan bahwa : "Setiap orang yang secara melawan hukum melakukan perbuatan memperkaya diri sendiri atau orang lain atau suatu korporasi yang dapat merugikan keuangan negara atau perekonomian negara, dipidana dengan pidana penjara seumur hidup atau pidana penjara paling singkat 4 (empat) tahun dan paling lama 20 (dua puluh) tahun dan denda paling sedikit Rp. 200.000.000,00 dua ratus juta rupiah) dan paling banyak Rp. 1.000.000.000.000,00 (satu milyar rupiah)."

Dalam penjelasannya disebutkan bahwa yang dimaksud dengan "secara melawan hukum" dalam pasal ini mencakup perbuatan melawan hukum dalam arti formil maupun dalam arti materil, yakni meskipun perbuatan tersebut tidak diatur dalam peraturan perundang-undangan, namun apabila perbuatan tersebut dianggap tercela karena tidak sesuai dengan rasa keadilan atau normanorma kehidupan sosial dalam masyarakat, maka perbuatan tersebut dapat dipidana. Dalam ketentuan ini, kata "dapat" sebelum frasa "merugikan keuangan atau perekonomian negara" menunjukkan bahwa tindak pidana korupsi merupakan delik formil, adanya tindak pidana korupsi cukup dengan dipenuhinya unsur-unsur perbuatan yang sudah dirumuskan bukan dengan timbulnya akibat.

Menurut Andi Hamzah, penerapan unsur melawan hukum secara materiel ini berarti asas legalitas di dalam Pasal 1 ayat (1) KUHP disingkirkan. Dengan adanya kata-kata "tidak sesuai dengan rasa keadilan" dan seterusnya, hal ini menjadi sangat luas sehingga sangat sulit bagaimana hakim dapat menyatakan bahwa unsur rasa keadilan masyarakat

\footnotetext{
33 Data diolah dari laman resmi Kantor Komisioner Tinggi HAM PBB, dapat diakses pada: http://tbinternet.ohchr. org/SitePages/Home.aspx.

34 Ibid.
} 
itu terbukti. Dapatkah dikatakan jika ada demontrasi menuntut seseorang sebagai koruptor merupakan manifestasi rasa keadilan masyarakat?. Jika demikian halnya, orang dapat mengumpulkan seribu orang dengan bayaran untuk berdemonstrasi menuntut seseorang sebagai koruptor, misalnya dengan motif politik. Gejala seperti ini sangat berbahaya bagi kepastian hukum dan telah terlihat pada beberapa kasus Pilkada. ${ }^{35}$ Selanjutnya ia katakan bahwa untuk merumuskan terbuktinya melawan hukum dalam arti materiel dengan rumus melanggar rasa keadilan masyarakat itu hakim harus menggali hukum yang hidup di dalam masyarakat sesuai dengan UndangUndang Pokok Kekuasaan Kehakiman dengan menanyai tokoh penting di dalam masyarakat apakah perbuatan terdakwa itu termasuk "tidak sesuai dengan norma-norma yang hidup di dalam kehidupan sosial masyarakat." Dengan sendirinya "melawan hukum secara materiel" untuk memperkaya diri sendiri atau orang Jain atau suatu korporasi bersifat relatif. ${ }^{36}$

Selajutnya menurut Indriyanto Seno Adji, perbuatan melawan hukum secara formil lebih dititikberatkan pada pelanggaran terhadap peraturan perundang-undangan yang tertulis, sedangkan suatu perbuatan dikatakan telah memenuhi unsur melawan hukum secara materil, apabila perbuatan itu merupakan pelanggaran terhadap norma kesopanan yang lazim atau kepatutan yang hidup dalam masyarakat. Dengan kata lain, setiap perbuatan yang dianggap atau dipandang tercela oleh masyarakat merupakan perbuatan melawan hukum secara materil. ${ }^{37}$ Pandangan ini sebenarnya merupakan reaksi atas pendapat yang menyatakan bahwa hukum adalah undangundang. Asas legalitas ("Principle of Legality") yang dapat disimpulkan melalui Pasal 1 ayat 1 KUHP mempunyai makna "Nullum Delictum, Noella Poena Sine Praevia Lega Poenali" (Tiada Delik, Tiada Pidana Tanpa Peraturan yang Mengancam Pidana Lebih Dulu), sehingga secara a contrario meskipun apabila perbuatan pelaku adalah "materiele wederrechtelijk" namun terbukti perbuatannya "formale" tidak "wederrechtelijk" dengan alasan tiadanya peraturan yang mempunyai sanksi pidana yang mengatur perbuatannya, maka terhadap pelakunya tidak dapat dipidana. Itulah salah satu alasan utama dihindarinya penerapan ajaran "materiele wederrechtelijkheid" dengan fungsi positif, karena penerapannya yang demikian itu akan dianggap melanggar asas legalitas dalam hukum pidana Indonesia, sehingga apabila tetap dipidananya pelaku terhadap perbuatan yang "materiele wederrechtelijk" meskipun "formale" perbuatannya tidak "wederrechtelijk", lanjut Vos, adalah jelas hakim telah melakukan penerapan analogi yang tidak sejalan dengan asas legalitas. ${ }^{38}$

Disamping pendapat tersebut di atas, terdapat beberapa pemikiran mengenai maksud dari perbuatan melawan hukum dalam arti formil maupun dalam arti materiil ini. Simons mengemukakan bahwa melawan hukumnya perbuatan dalam sudut formil,

Ibid, hal. 109.

Ibid, hal. 110

37 Indriyanto Seno Adji, Korupsi dan Penegakan Hukum,( Jakarta: Diadit Media, 2009), hal. 4.

$38 \quad$ Ibid, hal. 4-5 
artinya perbuatan melawan hukum yang bertentangan dengan peraturan-peraturan yang tertulis saja. Jadi setiap perbuatan melawan hukum adalah perbuatan yang bertentangan dengan Undang-undang (Wet) saja, karena hukum dipandang sama dengan Undangundang. ${ }^{39}$ Sedangkan perbuatan melawan hukum materil meliputi perbuatan-perbuatan yang dipandang bertentangan dengan norma kesopanan yang lazim atau bertentangan dengan keharusan dalam pergaulan hidup dalam masyarakat. Dengan kata lain perbuatan melawan hukum materil ini diartikan sebagai perbuatan-perbuatan yang dipandang tercela oleh masyarakat. Namun demikian, pengertian terhadap perbuatan melawan hukum secara materil haruslah diartikan secara Negatif. ${ }^{40}$

Lobby Loqman menggariskan arti Negatif dari perbuatan melawan hukum secara materil dengan menyatakan bahwa: "Melawan hukum secara materil haruslah digunakan secara negatif, ini berarti apabila terdapat suatu perbuatan nyata-nyata merupakan hal yang melawan hukum secara formil, sedangkan di dalam masyarakat perbuatan tersebut tidak tercela, jadi secara materil tidak melawan hukum, perbuatan tersebut seyogianya tidak dijatuhi pidana". ${ }^{41}$ Wirjono Prodjodikoro menyatakan pendapat yang sama bahwa "Adanya hukum pidana dengan tindak pidana yang dirumuskan di dalamnya itu bersumber pada pelanggaranpelanggaran hukum di bidang hukum lain itu. Jadi, dengan sendirinya dalam Tindak Pidana harus ada sifat melanggar hukum. Oleh karena yang dihilangkan itu ialah sifat melanggar hukum atau wederrechtelijkheid, sehingga perbuatan si pelaku menjadi diperbolehkan atau rechtmatig, maka alasan menghilangkan sifat tindak pidana (strafuitluitings-grond) ini juga dikatakan pada umumnya menghalalkan perbuatan mana yang pada umumnya merupakan tindak pidana (rechtvaardigings-grond)."

Jadi, perbuatan melawan hukum dalam arti materil pada penjelasan pasal 2 ayat (1) UUPTPK, mirip dengan Peraturan Penguasa Perang Pusat yang disebut dengan perbuatan korupsi bukan pidana. Oleh Undang-Undang (Prp) Nomor 24 Tahun 1960 perbuatan korupsi bukan pidana disebut perbuatan korupsi lainnya yang dikategorikan sebagai perbuatan melawan hukum. Namun perbuatan korupsi ini tidak diancam dengan hukum pidana, tetapi dapat merampas harta benda hasil perbuatan korupsi itu melalui putusan Pengadilan Tinggi. Tetapi perbuatan melawan hukum dalam arti materil ini meskipun perbuatan tersebut tidak diatur dalam peraturan perundang-undangan, namun apabila perbuatan tersebut dianggap tercela karena tidak sesuai dengan rasa keadilan atau norma-norma kehidupan sosial dalam masyarakat, maka perbuatan tersebut dapat dipidana. Hal inilah yang mengundang reaksi dari pakar hukum yang menganggap aturan ini bertentangan dengan asas legalitas yang dianut hukum pidana KUHP. Lagi pula ketentuan tersebut sangat sulit diterapkan terhadap korporasi yang melakukan perbuatan melawan hukum dalam tindak pidana korupsi. Sebab,

\footnotetext{
39 Indriyanto Seno Adji, Korupsi, Kebijakan Aparatur Negara dan Hukum Pidana, Jakarta, CV Diadit Media, 2007, hal. 63.

40 Ibid, hal. 63.

41 Ibid, hal. 63.

42 Ibid, hal. 64.
} 
korporasi tidak mungkin melakukan perbuatan tercela karena dia bukan manusia hanya disamakan dengan manusia atau manusia buatan.

\section{b. Bentuk Pertanggung jawaban Korporasi Dalam Tindak Pidana Korupsi}

Dalam hukum pidana harus ada kesalahan yang menyertai suatu perbuatan, yang mana perbuatan tersebut bertentangan dengan peraturan perundang-undangan. Jadi dalam konsep hukum pidana, hanya manusia yang dipandang dapat melakukan kesalahan dan sekaligus dimintakan pertanggung jawaban. Sudarto mengatakan bahwa asas kesalahan (geen straf zonder schuld) merupakan asas yang fundamental dalam pemidanaan. Meskipun orang telah melakukan tindak pidana, tidak selalu dipidana. Orang yang melakukan tindak pidana akan dijatuhi pidana apabila orang itu mempunyai kesalahan atau dapat dipertanggungjawabkan dalam hukum pidana. Kapan orang (pelaku atau pembuat) itu dikatakan mempunyai kesalahan?. Mengenai hal ini Sudarto menyatakan bahwa unsur-unsur kesalahan terdiri dari pertama, adanya kemampuan bertanggung jawab pada si pembuat (schuldfahigkeit atau zurechnungsfahigkeit), artinya keadaan jiwa si pembuat harus normal; kedua, hubungan batin antara si pembuat dengan perbuatannya yang berupa kesengajaan (dolus) atau kealpaan (culpa). Ini disebut bentuk-bentuk kesalahan; ketiga, tidak adanya alasan yang menghapuskan kesalahan atau tidak ada alasan pemaaf. ${ }^{43}$
Sehubungan dengan kemampuan bertanggung jawab korporasi sebagai subjek tindak pidana, muncul pertanyaan, untuk mempertanggungjawabkan korporasi, apakah diperlukan kemampuan bertanggungjawab? Nampaknya merupakan hal yang tidak mudah mencari dasar kemampuan bertanggungjawab korporasi, karena korporasi sebagai subyek tindak pidana tidak mempunyai sifat kejiwaan (kerohanian) seperti halnya manusia alamiah (naturlijk persoon). Namun demikian, persoalan tersebut dapat diatasi apabila kita menerima konsep kepelakuan fungsional (functioneel daderschap). ${ }^{44}$ Menurut Wolter, kepelakuan fungsional (functioneel daderschap) adalah karya interpretasi kehakiman. Hakim menginterpretasi tindak pidana itu sedemikian rupa sehingga pemidanaannya memenuhi persyaratan dari masyarakat. Ciri khas dari kepelakuan fungsional, yaitu perbuatan fisik dari yang satu (yang sebenarnya melakukan atau membuatnya) menghasilkan perbuatan fungsional terhadap yang lain. ${ }^{45}$ Apabila kita menerima konsep functioneel daderschap, maka kemampuan bertanggungjawab masih berlaku dalam mempertanggungjawabkan korporasi dalam hukum pidana. Sebab keberadaan korporasi tidaklah dibentuk tanpa suatu tujuan dan dalam pencapaian tujuan korporasi tersebut selalu diwujudkan melalui perbuatan manusia alamiah. Oleh karena itu kemampuan bertanggungjawab orang-orang yang berbuat untuk dan atas nama korporasi dialihkan 
menjadi kemampuan bertanggungjawab korporasi sebagai subyek tindak pidana. ${ }^{46}$

Unsur kedua dari pertanggungjawaban atau kesalahan dalam arti yang seluas-luasnya adalah hubungan batin antara pembuat dengan perbuatannya. Hubungan batin ini berupa kesengajaan dan kealpaan. KUHP kita tidak memberikan pengertian atau definisi tentang kesengajaan dan kealpaan. Namun kita dapat menemui pengertian dua hal tersebut dalam Memorie van Toelichting (M.v.T), yang mengartikan kesengajaan (opzet) sebagai 'menghendaki' dan mengetahui (willens end wetens). ${ }^{47}$ Sedangkan kealpaan dalam M.v.T dijelaskan bahwa pada umumnya bagi kejahatan, undang-undang mengharuskan bahwa kehendak terdakwa ditujukan kepada perbuatan yang dilarang dan diancam dengan pidana. Kecuali itu keadaan yang dilarang mungkin besar bahayanya terhadap keamanan umum mengenai orang atau barang dan jika terjadi akan menimbulkan banyak kerugian-kerugian sehingga undang-undang harus bertindak pula terhadap mereka yang tidak hati-hati. ${ }^{48}$ Untuk menentukan kesengajaan dan kealpaan dalam rangka mempertanggungjawabkan tindak pidana korporasi memang menjadi persoalan, karena korporasi tidak mempunyai sifat kejiwaan seperti layaknya manusia. Jadi tidaklah mungkin dapat menentukan antara hubungan batin sipembuat (dalam hal ini korporasi) dengan perbuatannya.

Selain bentuk pertanggungjawaban disebut diatas, Muladi menyebutkan model pertanggungjawaban korporasi, sebagai berikut: a. Pengurus korporasi sebagai pembuat dan penguruslah yang bertanggung jawab.

b. Korporasi sebagai pembuat dan pengurus bertanggung jawab.

c. Korporasi sebagai pembuat dan juga sebagai yang bertanggung jawab. ${ }^{49}$

Dalam hal pengurus korporasi sebagai pembuat dan penguruslah yang bertanggung jawab, kepada pengurus korporasi dibebankan kewajiban-kewajiban tertentu. Kewajiban yang dibebankan itu sebenarnya adalah kewajiban dari korporasi. Pengurus yang tidak memenuhi kewajiban diancam dengan pidana. Sehingga dalam sistem ini terdapat alasan yang menghapuskan pidana. Adapun dasar pemikirannya adalah: korporasi itu sendiri tidak dapat dipertanggungjawabkan terhadap suatu pelanggaran, tetapi selalu penguruslah yang melakukan delik itu. Dan karenanya penguruslah yang diancam pidana dan dipidana. ${ }^{50}$

Dalam hal korporasi sebagai pembuat dan pengurus bertanggungjawab, maka ditegaskan bahwa korporasi mungkin sebagai pembuat. Pengurus ditunjuk sebagai yang bertanggung jawab; yang dipandang dilakukan oleh korporasi adalah apa yang dilakukan oleh alat perlengkapan korporasi menurut wewenang berdasasrkan anggaran dasarnya. Tindak pidana yang dilakukan korporasi adalah tindak pidana yang dilakukan seseorang tertentu sebagai pengurus dari badan hukum tersebut. Sifat dari perbuatan yang menjadi tindak pidana itu adalah onpersoonlijk. Orang yang memimpin korporasi bertanggung jawab pidana, terlepas

\footnotetext{
46 Ibid, hal. 134.

47 Ibid, hal. 134.

48 Ibid, hal. 135-136.

49 Muladi dan Dwidja Priyatno, Op. cit, hal. 86.

50 Muladi dan Dwidja Priyatno, Ibid, hal. 86
} 
dari apakah ia tahu ataukah tidak tentang dilakukannya perbuatan itu. ${ }^{51}$

Korporasi sebagai pembuat dan juga sebagai yang bertanggung jawab motivasinya adalah dengan memperhatikan perkembangan korporasi itu sendiri, yaitu bahwa ternyata untuk beberapa delik tertentu, ditetapkannya pengurus saja sebagai yang dapat dipidana ternyata tidak cukup. Dalam delik ekonomi bukan mustahil denda yang dijatuhkan sebagai hukuman kepada pengurus dibandingkan dengan keuntungan yang telah diterima oleh korporasi dengan melakukan perbuatan itu, atau kerugian yang ditimbulkan dalam masyarakat, atau yang diderita oleh saingannya, keuntungan dan/atau kerugian itu adalah lebih besar daripada denda yang dijatuhkan sebagai pidana. Dipidananya pengurus tidak memberikan jaminan yang cukup bahwa korporasi tidak sekali lagi melakukan perbuatan yang telah dilarang oleh undang-undang itu. ${ }^{52}$

Mengenai dapat dipidananya korporasi terdapat pengaturannya dalam UndangUndang Nomor 7 Drt 1955 tentang Pengusutan, Penuntutan dan Peradilan Tindak Pidana Ekonomi (UUTPE) dimana dalam Pasal 15 ayat (1) disebutkan: "Jika suatu tindak pidana ekonomi dilakukan oleh atau atas nama suatu badan hukum, suatu perseroan, suatu perserikatan orang yang lainnya atau suatu yayasan, maka tuntutan pidana dilakukan dan hukuman pidana serta tindakan tata tertib dijatuhkan, baik terhadap badan hukum, perseroan, perserikatan atau yayasan itu, baik terhadap mereka yang memberi perintah melakukan tindak pidana ekonomi itu atau yang bertindak sebagai pemimpin dalam perbuatan atau kelalaian itu, maupun terhadap keduaduanya."

Dalam penjelasannya Pasal 15 disebutkan bahwa hukuman atau tindakan dapat dijatuhkan juga terhadap badan-badan hukum, perseroanperseroan, perserikatan-perserikatan dan yayasan-yayasan. Dalam hukum pidana ekonomi aturan itu sangat dibutuhkan, oleh karena banyak tindak pidana ekonomi dilakukan oleh badan-badan itu. IImu hukum pidana modern telah mengakui ajaran, bahwa hukuman dapat diucapkan terhadap suatu badan hukum.

Jadi dalam hukum pidana khusus yaitu hukum pidana ekonomi dimungkinkan penjatuhan pidana pada korporasi sebagaimana yang ditentukan dalam UUTPE. Hal ini juga telah diterapkan dalam ketentuan pidana di bidang perbankan, pasar modal dan sebagainya. Namun prakteknya penjatuhan hukuman pada korporasi dalam tindak pidana lembaga keuangan tersebut, lebih menekankan pada pidana denda. Menjadi pertanyaan bagaimana pertanggungjawaban korporasi pada tindak pidana korupsi?. Jika menelisik ketentuan UUPTPK Pasal 1 ayat (3) dikatakan bahwa perkataan "Setiap orang" dalam Undangundang tersebut adalah termasuk korporasi. Berarti korporasi adalah sebagai subjek hukum disamping manusia. Dengan demikian Pasal 2 ayat (1) UUPTPK dengan sendirinya berlaku bagi korporasi yang melakukan tindak pidana korupsi, yaitu "melakukan perbuatan melawan hukum memperkaya diri sendiri atau orang lain atau korporasi yang dapat merugikan keuangan negara dan perekonomian negara, di pidana

51 Ibid, hal. 89.

52 Ibid, hal. 90. 
dengan pidana penjara paling singkat 4 (empat) tahun dan denda paling sedikit duaratus juta rupiah dan paling banyak satu miliar rupiah."

Jika yang dimaksud setiap orang termasuk korporasi berarti korporasi dapat melakukan tindak pidana korupsi sehingga dijatuhi pidana penjara menurut Pasal 2 ayat (1) UUPTPK. Tetapi timbul masalah bagaimana mungkin menjatuhkan pidana penjara pada korporasi, karena ia bukan manusia. Jika kita mengikuti penjelasan Pasal 2 ayat (1) ini, juga tidak menjelaskan bagaimana penjatuhan pidana pada korporasi. Hanya menjelaskan maksud "secara melawan hukum" itu mencakup perbuatan melawan hukum dalam artiformil dan arti materil, yakni meskipun perbuatan tersebut tidak diatur dalam peraturan perundangundangan, namun apabila perbuatan tersebut dianggap tercela karena tidak sesuai dengan rasa keadilan atau norma-norma kehidupan sosial dalam masyarakat, maka perbuatan tersebut dapat dipidana. Penjelasan tersebut semakin jauh dari maksud penjatuhan pidana pada korporasi. Sebab perbuatan tercela hanya dapat dilakukan oleh manusia karena tidak mungkin korporasi dapat melakukan perbuatan demikian. Oleh karena itu, penerapan Pasal 2 ayat (1) ini sangat tidak mungkin dijatuhkan pada tindak pidana korupsi korporasi. Sebab perbuatan tindak pidana tersebut hanya dapat dilakukan oleh manusia. Pada hal Pasal 2 ayat (1) UUPTPK inilah yang menjadi pintu masuk untuk mengatakan dapat tidaknya seseorang atau korporasi melakukan perbuatan melawan hukum, sehingga perbuatannya tersebut dapat dijatuhkan pidana.

Dari sejumlah pasal-pasal yang terdapat dalam UUPTPK, maka yang paling tepat dapat diterapkan dalam menjerat korporasi yang melakukan tindak pidana korupsi adalah Pasal
18 ayat (1) dan Pasal 20 UUPTPK. Pasal 18 ayat (1) UUPTPK adalah mengenai pidana tambahan, yaitu:

1) perampasan barang bergerak yang berwujud atau yang tidak berwujud atau barang tidak bergerak yang digunakan untuk atau yang diperoleh dari tindak pidana korupsi, termasuk perusahaan milik terpidana di mana tindak pidana korupsidilakukan, begitu pula harga dari barang yang menggantikan barang-barang tersebut;

2) pembayaran uang pengganti yang jumlahnya sebanyak-banyaknya sama dengan harta benda yang diperoleh dari tindak pidana korupsi;

3) penutupan seluruh atau sebagian perusahaan untuk waktu paling lama 1 (satu) tahun;

4) pencabutan seluruh atau sebagian hakhak tertentu atau penghapusan seluruh atau sebagian keuntungan tertentu, yang telah atau dapat diberikan oleh Pemerintah kepada terpidana.

Selanjutnya Pasal 20 UUPTPK menyebutkan:

1) Dalam hal tindak pidana korupsi dilakukan oleh atau atas nama suatu korporasi, maka tuntutan dan penjatuhan pidana dapat dilakukan terhadap korporasi atau pengurusnya.

2) Tindak pidana korupsi dilakukan oleh korporasi apabila tindak pidana tersebut dilakukan oleh orang-orang baik berdasarkan hubungan kerja maupun berdasarkan hubungan lain, bertindak dalam lingkungan korporasi tersebut baik sendiri maupun bersama-sama.

3) Dalam hal tuntutan pidana dilakukan terhadap suatu korporasi, maka korporasi tersebut diwakili oleh pengurus. 
Dengan demikian perbuatan melawan hukum dalam tindak pidana korupsi korporasi dapat dimintakan pertanggungjawaban dengan penjatuhan pidana tambahan seperti perampasan barang bergerak atau tidak bergerak, pembayaran uang pengganti, pencabutan ijin dan sebagainya. Hanya saja dalam prakteknya pidana tambahan ini sangat jarang dilakukan, meskipun banyak pihak yang menginginkan penjatuhan sanksi pidana pada korporasi. Menurut penulis, hakim dalam memeriksa dan memutus perkara memiliki pertimbanganpertimbangan tidak saja dari segi juridis tapi juga segi sosiologis dan ekonomis, sehingga sangat hati-hati sekali dalam penjatuhan sanksi pidana tambahan tersebut. Apabila dijatuhkan sanksi tambahan pada korporasi seperti pencabutan ijin, kemungkinan akan memberi dampak pada pekerja dan keluarganya, pemegang saham, perusahaan rekanan dan masyarakat sekitarnya, yang selama ini menggantungkan hidup dari perusahaan tersebut. Jadi, penjatuhan sanksi pada perusahaan tersebut malah dapat menimbulkan masalah baru yang lebih luas. Inilah yang menurut hemat penulis mengapa hakim sangat jarang menjatuhkan pidana pada korporasi.

Selain itu, kesulitan menjerat korporasi berdasarkan UUPTPK tersebut adalah disebabkan karena konsep pemikiran dalam UUPTPK, sebagian besar merupakan konsep pemikiran KUHPidana. Sekitar 13 (tiga belas) Pasal KUHP diambil alih (take over) oleh UUPTPK dengan hanya memperberat sanksi hukumnya saja. Oleh karena konsep UUPTPK ini sebagian besar berasal dari KUHPidana, maka terlalu dipaksakan korporasi dijadikan sebagai subjek hukum. Mengapa dikatakan demikian, karena konsep pemikiran yang terkandung dalam KUHPidana hanya mengenal manusia sebagai subjek hukum, tidak mengenal korporasi sebagai subjek hukum. Sehingga, ketika korporasi dinyatakan melakukan perbuatan melawan hukum dalam arti formiil (Pasal 2 ayat (1) UUPTPK) menimbulkan kebingungan, bagaimana menjerat korporasi dengan ancaman pidana penjara. Tentu tidak mungkin sebab dia bukan manusia lagi pula tujuan pemidanaan penjara menurut konsep KUHPidana hanya ditujukan pada manusia bukan pada subjek hukum lainnya.

Inilah problematika sebuah peraturan perundang-undangan yang mengambilalih berbagai materi peraturan perundangundangan lainnya dan memaksakan masuk kedalam sistem yang dikehendaki oleh peraturan baru tersebut. Hasilnya menjadi sulit untuk diterapkan dalam praktek, karena disebabkan terjadinya perberdaan konsep antara UUPTPK dengan KUHPidana.

\section{Penutup}

Pada tindak pidana khusus di bidang ekonomi sebagaimana diatur UUTPE Nomor 7 Drt 1955 dalam Pasal 15, telah menetapkan pertanggungjawaban pidana suatu badan hukum. Apabila suatu badan hukum melakukan tindak pidana ekonomi, maka dapat dijatuhkan sanksi pidana. UUPTPK sebagai peraturan tindak pidana khusus di bidang korupsi, telah pula mengatur penjatuhan sanksi pidana terhadap korporasi yang melakukan tindak pidana korupsi. Namun tindak pidana korporasi dalam delik korupsi ini hanya dikategorikan sebagai perbuatan melawan hukum dalam arti formil tidak dalam arti materil. Sebab, korporasi tidak mungkin dapat dipidana penjara atau melakukan perbuatan tercela seperti melanggar rasa keadilan masyarakat dan norma-norma kehidupan masyarakat. 
Sehingga perumusan Pasal 2 ayat (1) UUPTPK berikut penjelasannya, sangat sulit dipaksakan untuk menjerat korporasi. Sebab perbuatan tindak pidana tersebut hanya dapat dilakukan oleh manusia. Pada hal Pasal 2 ayat (1) inilah yang menjadi pintu masuk untuk mengatakan dapat tidaknya korporasi melakukan perbuatan melawan hukum, sehingga dapat dijatuhkan pidana. Kesulitan penjatuhan pidana pada korporasi tersebut disebabkan karena karena konsep UUPTPK ini berasal dari KUHPidana, hanya mengenal manusia sebagai subjek hukum dan tidak mengenal korporasi sebagai subjek hukum. Oleh karena itulah, sangat sulit menetapkan kesalahan pada korporasi, karena yang dapat melakukan kesalahan itu hanya lah manusia. Bentuk pertanggungjawaban korporasi dalam perbuatan melawan hukum tindak pidana korporasi, hanya dapat dijatuhkan pidana pengganti. Apabila tindak pidana korupsi dilakukan atas nama korporasi, maka penjatuhan pidana dapat dilakukan terhadap korporasi atau pengurusnya atau orang lain yang terkait dengan korporasi. Dasar hukum penjatuhan sanksi pidana terhadap korporasi yang melakukan tindak pidana korupsi diatur dalam Pasal 18 ayat (1) huruf a,b,c,d dan ayat (2) serta Pasal 20 UUPTPK.

Jika Rancangan Undang-undang (RUU) KUHPidana baru sudah disahkan dan didalamnya telah mengatur subjek hukum korporasi, maka menurut penulis sebaiknya ketentuan UUPTPK ini dicabut saja agar tidak timbul duplikasi dan perbedaan penafsiran dalam menangani tindak pidana korupsi korporasi atau paling tidak agar selaras peraturan pidana umum dengan peraturan pidana khusus korupsi.

Sanksi pidana tambahan sebagaimana diatur dalam Pasal 18 ayat (1) huruf a dan b, dapat saja dijatuhkan hakim, tapi terbatas pada perampasan barang bergerak yang berwujud atau tidak berwujud atau barang tidak bergerak dan pembayaran uang pengganti sebesar yang diperoleh dari hasil tindak pidana korupsi. Tetapi penjatuhan sanksi berdasarkan Pasal 18 ayat (1) huruf $c$ dan d seperti penutupan perusahaan dan pencabutan hak-hak tertentu atau penghapusan seluruh atau sebagian keuntungan, sebaiknya sanksi tersebut tidak dijatuhkan hakim. Sebab, penjatuhan pidana tidak semata-mata hanya pada pertimbangan-pertimbangan segi juridis belaka, tapi juga harus memperhatikan segi sosiologis dan ekonomisnya. Jika harus menjatuhkan sanksi berdasarkan point c dan d tersebut dikhawatikan akan membawa kerugian yang lebih besar dalam masyarakat, yaitu mereka yang menggantungkan hidup pada perusahaan tersebut seperti karyawan dan keluarganya, perusahaan pemasok barang dan usaha-usaha kecil disekitar perusahaan. Pemegang saham, yang tidak ikut campur dalam pengurusan perusahaan, juga akan dirugikan dengan penjatuhan sanksi tersebut.

\section{DAFTAR PUSTAKA}

\section{Buku}

Ali, Chidir, Badan Hukum, (Bandung: Alumni, 2005). Atmasasmita, Romli, Perbandingan Hukum Pidana, (Bandung: Mandar Maju, 2000).

Adji, Indriyanto Seno, Korupsi dan Penegakan Hukum, (Jakarta: Diadit Media, 2009).

Adji, Indriyanto Seno, Korupsi, Kebijakan Aparatur Negara dan Hukum Pidana, (Jakarta, CV Diadit Media, 2007).

Hamzah, Andi, Pemberantasan Korupsi Melalui Hukum Pidana Nasional dan Internasional, (Jakarta: Rajawali Pers, 2012).

Hutauruk, Rufinus Hotmaulana, Penanggulangan Kejahatan Korporasi Melalui Pendekatan Restoratif: suatu terobosan hukum, (Jakarta: Sinar Grafika, 2013).

Koesoemahatmadja, Etty Utju R., Hukum Korporasi, Penegakan Hukum terhadap Pelaku Economic 
Crimes dan Perlindungan Abuse of Power, (Bogor: Penerbit Ghalia Indonesia, 2011).

Lumintang, P.A.F., Dasar-Dasar Hukum Pidana Indonesia, (Bandung : Citra Aditya Bakti, 1997).

Muladi dan Priyatno, Dwidja, Pertanggungjawaban

Pidana Korporasi, (Jakarta: Prenadamedia, 2013).

Moeljatno, Asas-asas Hukum Pidana, (Jakarta: Rineka Cipta, 2009).

Nurdjana, IGM., Sistem Hukum Pidana dan Bahaya Laten Korupsi: "Perspektif Tegaknya Keadilan Melawan Mafia Hukum", (Yogyakarta: Pustaka Pelajar, 2010).

Prodjohamidjojo, Martiman, Memahami DasarDasar Hukum Pidana Indonesia, (Jakarta: Pradnya Paramita, 1997).
Setiyono, H., Kejahatan Korporasi: Analisis Viktimonologis Dan Pertanggungjawaban Korporasi Dalam Hukum Pidana Indonesia, (Malang : Averros Press, 2002).

Sianturi, S.R., Asas-asas Hukum Pidana di Indonesia dan Penerapannya, (Jakarta: Alumni AHAEM PETEHAEM, 1996).

Sudarto, Kapita Selekta Hukum Pidana, (Bandung: Alumni, 1986).

\section{Internet:}

http://nasional.kompas.com/read/2013/07/30/ 1320464 (diakses 15 September 2014)

http://nasional.inilah.com/read/detail/2063880/ (diakses 15 September 2014)

http://www.antikorupsi.org/en/content/ (diakses 15 September 2014) 